Jurnal Ilmiah ESAI Volume 13, No. 2, Juli 2019

p-ISSN 1978-6034 e-ISSN 2580-4944

The Influence of Cash Turnover, Working Capital,and Accounts Receivable Turnover towards Liquidity (Current Ratio) Listed on the Indonesia Stock Exchange for the Period of 2014-2017

\title{
Pengaruh Perputaran Kas, Modal Kerja dan Perputaran Piutang terhadap Likuiditas (Current Ratio) pada Perusahaan Consumer Goods yang Terdaftar di Bursa Efek Indonesia Periode 2014-2017
}

\author{
Henny Indriani Susantri Manullang ${ }^{1)}$, Enda Noviyanti Simorangkir ${ }^{2)}$, Desy Octavia ${ }^{3)}$, Dessy Kristy \\ Parapat $^{4}$, Winarti Halawa ${ }^{5}$, Maritta Hirawati ${ }^{6}$ \\ 1,2,3,4,5) Program studi Akuntansi Keuangan, Jurusan Akuntansi, Universitas Prima Indonesia, Medan \\ e-mail: Hennymanullang60@gmail.com
}

\begin{abstract}
This study aims to examine the effect of cash turnover, working capital and accounts receivable turnover towards liquidity (current ratio) in consumer goods companies listed on the Indonesia Stock Exchange (IDX) for the 2014-2017 period both simultaneously and partially and to find out which variables are free, and which has a significant effect on liquidity in consumer goods companies listed on the Indonesia Stock Exchange. The population in this study - 24 Consumer Goods companies - was defined through purposive sampling method in the Consumer Goods companies listed on the Indonesia Stock Exchange (IDX) during the 2014-2017 period as well as predetermined criteria. The research applied analytical method of multiple linear regression analysis with SPSS 22 tools. The results of the hypothesis testing of the T-test show that cash turnover variables have an effect on significant liquidity while working capital and receivable turnover variables do not affect the liquidity in Consumer Goods companies in Indonesia stock exchange.
\end{abstract}

Keywords : cash turnover, working capital, accounts receivable turnover, liquidity, current ratio

\section{Pendahuluan}

Pasar modal dalam suatu negara memiliki peranan yang penting dalam menunjang perekonomian negara tersebut karena pasar modal merupakan suatu wadah yang mempertemukan banyak pihak yang kelebihan dana dan pihak yang kekurangan dana. Di Indonesia sendiri pasar modal menunjukkan perkembangan yang cukup baik.

Hal tersebut dibuktikan dengan semakin bertambahnya perusahaan-perusahaan yang tercatat dalam Bursa Efek Indonesia yang selanjutnya menjadi perusahaan yang go public karena perusahaan-perusahaan tersebut menerbitkan saham dan memperdagangkannya di bursa efek.

Setiap perusahaan dituntut harus bisa mengelola perusahaannya dengan baik agar dapat bersaing dengan perusahaan-perusahaan lain baik bagi perusahaan domestik maupun perusahaan asing. Hal ini dapat dilakukan dengan memperhatikan tingkat perputaran kas 
dan perputaran piutang perusahaan tersebut. Karena kedua rasio tersebut sangat penting bagi perusahaan untuk mengukur efisiensi penggunaan modal kerja sehingga perusahaan terhindar dari gagal bayar atas hutang jangka pendeknya. Tingkat perputaran kas merupakan rasio untuk mengukur kemampuan perusahaan dalam membayar kewajiban jangka pendek dengan kas yang tersedia. Suatu perusahaan yang memiliki likuiditas tinggi karena adanya kas dalam jumlah besar berarti tingkat perputaran kas tersebut rendah dan mencerminkan adanya kelebihan kas. Sebaliknya apabila jumlah kas relative kecil berarti perputaran kas tinggi sehingga perusahaan akan atau dapat berada dalam keadaan likuid. Tingkat perputaran kas yang tinggi menunjukkan kecepatan arus kas kembali dari kas yang telah diinvestasikan pada aktiva.

Piutang merupakan aktiva lancar perusahaan yang timbul sebagai akibat praktik penjualan kredit. Tingkat perputaran piutang adalah rasio yang memperlihatkan lamanya untuk mengubah piutang menjadi kas. Semakin tinggi tingkat perputaran piutang maka semakin cepat pula menjadi kas dan apabila piutang telah menjadi kas berarti kas dapat digunakan kembali dalam operasional perusahaan serta resiko kerugian piutang dapat diminimalkan sehingga perusahaan dapat dikategorikan perusahaan likuid. Dan, apabila tingkat perputaran piutang rendah, maka akan terjadi kelebihan piutang dan perusahaan akan mengalami kadaan illikuid.
Salah satu faktor yang dapat mempengaruhi kelangsungan perusahaan juga adalah masalah working capital. Manajemen modal kerja yang baik sangat penting dalam bidang keuangan karena kesalahan dan kekeliruan dalam mengelola working capital dapat mengakibatkan kegiatan usaha menjadi terhambat atau terhenti sama sekali. Sehingga adanya analisis atas working capital perusahaan sangat penting untuk dilakukan karena meliputi pengambilan keputusan mengenai jumlah dan komposisi aktiva lancar dan bagaimana membiayai aktiva ini. Dan perusahaan yang tidak dapat memperhitungkan tingkat modal kerja yang memuaskan, maka perusahaan kemungkinan tidak mampu memenuhi kewajiban jatuh tempo dan bahkan mungkin terpaksa harus dilikuidasi.

Rumusan masalah penelitian ini adalah: 1) bagaimana pengaruh perputaran Kas terhadap likuiditas pada sektor Industri Barang Konsumsi yang terdaftar di Bursa Efek Indonesia periode 2014-2017; 2) bagaimana pengaruh Modal kerja terhadap likuditas pada sektor Industri Barang Konsumsi yang terdaftar di Bursa Efek Indonesia 2014-2017; 3) bagaimana Piutang terhadap likuiditas pada sektor Industri Barang Konsumsi yang telah terdaftar di Bursa Efek Indonesia 2014-2017; dan 4) bagaimana perputaran Kas, Modal Kerja, Piutang terhadap likuiditas pada sektor Industri Barang Konsumsi yang telahterdaftar di Bursa Efek Indonesia 2014-2017.

Penelitian ini bertujuan untuk: 1) menguji dan menganalisis pengaruh Perputaran Kas terhadap likuiditas pada sektor 
Industri Barang Konsumsi yang telah terdaftar di Bursa Efek Indonesia 2014-2017; 2) menguji dan menganalisis Modal Kerja terhadap likuiditas pada sektor Industri Barang Konsumsi yang telah terdaftar di Bursa Efek Indonesia 2014-2017; 3) menguji dan menganalisis Piutang terhadap likuiditas pada sektor Industri Barang Konsumsi yang telah terdaftar di Bursa Efek Indonesia 2014-2017; dan 4) menguji dan menganalisis pengaruh Perputaran Kas, Modal Kerja, Piutang terhadap likuiditas pada sektor Industri Barang Konsumsi yang telah terdaftar di Bursa Efek Indonesia 2014-2017.

\section{Tinjauan Pustaka}

\section{Perputaran Kas}

Menurut Rudianto (2009:200), perputaran kas merupakan alat pembayaran yang dimiliki perusahaan dan siap digunakan didalam transaksi perusahaan setiap saat diinginkan. Menurut Hery (2015:24) rumus yang digunakan dalam mencari perputaran kas yaitu :

$$
\text { Perputaran kas }=\frac{\text { Penjualan bersih }}{\text { Rata-rata kas }}
$$

\section{Modal Kerja}

$$
\text { Menurut Jumingan (2014:66), }
$$
terdapat dua definisi modal kerja yaitu modal kerja adalah kelebihan aktiva lancar terhadap utang jangka pendek dan modal kerja adalah jumlah dari aktiva lancar. Menurut Sunyoto (2013:127) rumus modal kerja adalah sebagai berikut :

\section{Modal kerja bersih = aktiva lancar - kewajiban lancar}

\section{Perputaran Piutang}

$$
\text { Menurut Sudana }
$$

(2011:22), receivable turnover mengukur perputaran piutang dalam menghasilkan penjualan. Semakin tinggi perputaran piutang berarti semakin efektif dan efesien. Menurut M Hanafi (2012:205) rumus untuk mencari perputaran piutang yaitu :

$$
\text { Perputaran piutang }=\frac{\text { PenjualanKredit }}{\text { Piutang }}
$$

\section{Likuiditas (Current Ratio)}

Menurut Kasmir (2012:129), likuiditas adalah rasio untuk menunjukan atau mengukur kemampuan perusahaan dalam memenuhi kewajibannya yang sudah jatuh tempo, baik kewajiban kepada pihak luar perusahaan maupun di dalam perusahaan. Menurut Irham Fahmi (2014:67) rumus untuk mencari likuidititas yaitu:

$$
\text { Current Ratio }=\frac{\text { Aktivalancar }}{\text { UtangLancar }}
$$

\section{Metode Penelitian}

\section{Jenis Penelitian}

Jenis penelitian dalam penelitian ini mengunakan penelitian statistik deskriptif yang digunakan untuk menganalisis data dengan cara mendeskripsikan atau menggabarkan data yang telah terkumpul sebagaimana adanya tanpa maksud membuat kesimpulan yang berlaku untuk umum atau generalisasi.

\section{Tempat dan Waktu Penelitian}

Peneliti melakukan penelitian pada perusahaan Costomer Goods yang terdaftar di Bursa Efek Indonesia periode 2014-2017 melalui media internet dengan situs www.idx.co.id. 


\section{Populasi dan Sampel}

Populasi dalam penelitian ini adalah laporan keuangan Perusahaan Consumer Goods yang terdaftar di Bursa Efek Indonesia periode 2014-2017. Berdasarkan penarikan sampel maka diperoleh perusahaan dengan menggunakan data runtun waktu (time series) tahun 2014-2017 sehingga diperoleh sampel sebanyak 96 data diperoleh dari 24 perusahaan dikali 4 tahun.

\section{Metode Pengumpulan Data}

Teknik pengumpulan data dilakukan dengan dua tahap, tahap pertama dilakukan melalui studi pustaka, yaitu melalui penelitian terdahulu, buku-buku yang berkaitan dengan masalah yang diteliti. Pada tahap kedua, pengumpulan data sekunder diperoleh dari media internet melalui situs www.idx.co.id untuk memperoleh data mengenai laporan keuangan yang dibutuhkan dalam penelitian ini.

\section{Statistik Deskriptif}

Statistik deskriptif memberikan gambaran mengenai nilai minimum, nilai maksimum, nialai rata-rata serta standar deviasi data yang digunakan dalam penelitian.

\section{Uji Normalitas}

Uji normalitas bertujuan untuk menguji apakah dalam model regresi, variabel panggangu atau residual memiliki distribusi normal. Seperti diketahui bahwa uji Tdan uji F mengasumsikan bahwa nilai residual mengikuti distribusi normal. Kalau asumsi ini dilanggar maka uji statistik menjadi tidak valid untuk jumlah sampel kecil.

\section{Uji Multikolonieritas}

Uji Multikolonieritas bertujuan untuk menguji apakah model regresi ditemukan adanya korelasi antar variabel bebas (independen). Model regresi yang baik seharusnya tidak terjadi korelasi di antara variabel independen. Jika variabel independen saling berkorelasi, maka variabel-variabel ini tidak ortogonal. Variabel ortogonal adalah variabel independen yang nilai korelasi antar sesama variabel independen sama dengan nol.

\section{Uji Autokorelasi}

Uji autokorelasi bertujuan untuk menguji apakah dalam model regresi linear ada korelasi antara kesalahan penganggu pada periode $\mathrm{t}$ dengan kesalahan penganggu pada periode t-1 (sebelumnya). Jika terjadi korelasi, maka dinamakan ada problem autokorelasi. Autokorelasi muncul karena observasi yang berurutan sepanjang waktu berkaitan satu sama lainnya. Masalah ini timbul karena residual (kesalahan penggangu) tidak bebas dari satu observasi ke observasi lainnya.

\section{Uji Heteroskedastisitas}

Uji Heteroskedastisitas bertujuan untuk menguji apakah dalam model terjadi ketidaksamaan variance dari residual atau pengamatan kepengamatan yang lain. Model regresi yang baik adalah yang Homoskedastisitas atau tidak terjadi Heteroskedastisitas. Ada beberapa cara untuk mendeteksi ada atau tidaknya heteroskedastisitas yaitu dengan grafik scatter plot dan uji glejser. 


\section{Analisis Linear Berganda}

Model penelitian ini menggunakan analisi linear berganda yang digunakan untuk mengetahui ada atau tidaknya pengaruh antar variabel independen terhadap variabel dependen. Rumus dalam perhitungan regresi linear berganda menggunakan aplikasi statistik SPSS yaitu :

$$
\mathbf{Y}=\mathbf{a}+\mathbf{b}_{1} \mathbf{X}_{1}+\mathbf{b}_{2} \mathbf{X}_{2}+\mathbf{b}_{3} \mathbf{X}_{3}+\mathbf{e}
$$

\section{Uji Hipotesis Secara Simultan (Uji F)}

Uji Hipotesissecara simultan bertujuan untuk menguji signifikan pengaruh dimensi variabel bebas secara serempak terhadap variabel terikat dilakukan dengan uji-F.

\section{Uji Hipotesis Secara Parsial (Uji T)}

Uji $t$ adalah untuk menguji hipotesis secara parsial antara masing-masing variabel bebas terhadap variabel terikat.

\section{Uji Koefisien Determinasi $\left(\mathbf{R}^{2}\right)$}

Koefisien determinasi pada intinya mengukur seberapa jauh kemampuan model dalam menerangkan variasi variabel independen. Nilai Adjusted $\mathrm{R}^{2}$ dapat bernilai negatif, walaupun yang dikehendaki harus bernilai positif. Dalam uji empiris di dapat nilai adjusted $\mathrm{R}^{2}$ negatif, maka nilai adjusted $\mathrm{R}^{2}=0$. Secara sistematis $\mathrm{R}^{2}=1$, maka adjusted $\mathrm{R}^{2}=\mathrm{R}^{2}=1$ sedangkan jika nilai $\mathrm{R}^{2}=0$, maka adjusted $\mathrm{R}^{2}=(1-\mathrm{k}) /(\mathrm{n}-\mathrm{k})$. Jika $\mathrm{k}>1$, maka nilai adjusted $\mathrm{R}^{2}$ akan bernilai negatif.

\section{Hasil Dan Pembahasan}

Tabel 1. Deskriptif Statistik Penelitian

\section{Descriptive statisrice}

\begin{tabular}{lcrrrr}
\hline & $\mathrm{N}$ & Minimum & Maximum & \multicolumn{1}{c}{ Mean } & \multicolumn{1}{c}{ Std. Deviasi } \\
\hline PERPUTARAN KAS & 96 & -15.78 & 261.31 & 29.2105 & 56.94791 \\
MODAL KERJA & 96 & $-4.59 \mathrm{E} 12$ & $2.77 \mathrm{E} 13$ & $3.448 \mathrm{E} 12$ & $6.52750 \mathrm{E} 12$ \\
PERPUTARAN PIUTANG & 96 & .00 & 45.15 & 4.7468 & 5.12355 \\
LIKUIDITAS & 96 & .13 & 10.25 & 2.9386 & 2.03455 \\
Valid N (listwise) & 96 & & & & \\
\hline
\end{tabular}

Sumber : Hasil Pengolahan Data, 2019

Tabel 1 tersebut menunjukkan nilai minimum, maksimum, nilai rata-rata (mean), dan standar deviasi dari variabel Perputaran Kas, Modal Kerja, Perputaran Piutang, dan Likuditas (CR) dengan rincian sebagai berikut: 1) Variabel Perputaran Kas memiliki nilai minimum sebesar -15,78 oleh PT Sekar Laut Tbk pada tahun 2015 dan nilai maksimum sebesar 261,31 oleh PT Wilmar Cahaya Indonesia Tbk pada tahun 2016, dengan nilai mean sebesar 29,2105 dan nilai standar deviasi sebesar 56,94791; 2) Variabel Modal Kerja memiliki nilai minimum sebesar 4.590.669.000.000 oleh PT Unilever Indonesia Tbk pada tahun 2017 dan nilai maksimum sebesar 27.697.384.000.000 dengan nilai mean 
sebesar 3.448 dan nilai standar deviasi sebesar 6.5275; 3) Variabel Perputaran Piutang memiliki nalai minimum sebesar 0,00 pada PT Merck Tbk pada tahun 2015 dan nilai maksimum sebesar 45,15 pada PT Chitose International Tbk pada tahun 2017 dengan nilai mean sebesar 4,7468 dan nilai standar deviasi sebesar 5,12355; dan 4) Variabel Likuiditas (CR) memiliki nilai minimum sebesar 0,13 pada PT Sekar Laut Tbk pada tahun 2016 dan nilai maksimum sebesar 10,25 pada PT Industri Jamu dan Farmasi Sido Muncul pada tahun 2014, dengan nilai mean sebesar 2,9386 dan nilai standar deviasi sebesar 2.03455 .

\section{Hasil Penelitian Uji Normalitas}

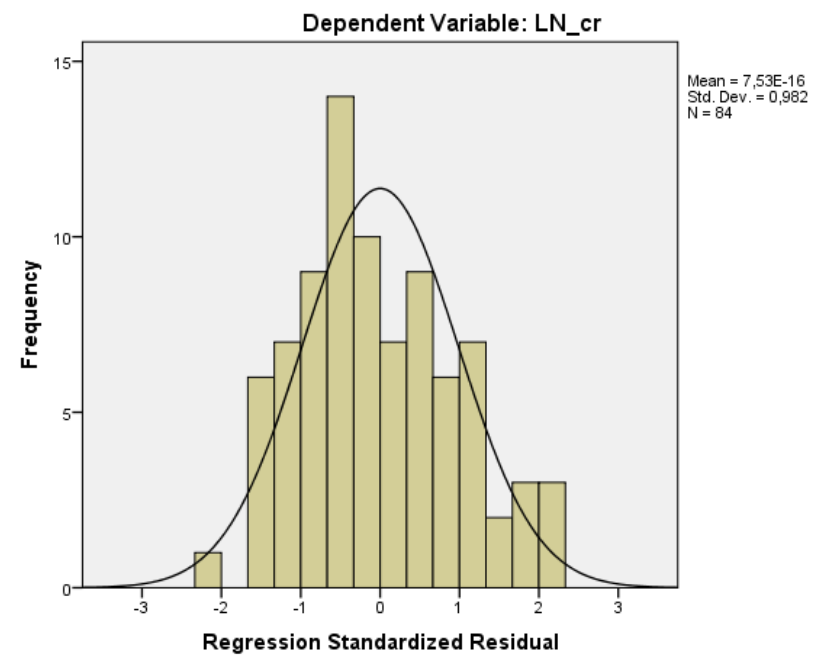

Gambar 1. Uji Normalitas Histogram

Sumber : Hasil Pengolahan Data, 2019

Hasil uji grafik histogram pada Gambar 1 menujukkan garis kurva cenderung simetri. Hal ini menunjukkan bahwa data berdistribusi normal dan memenuhi asumsi normalitas.

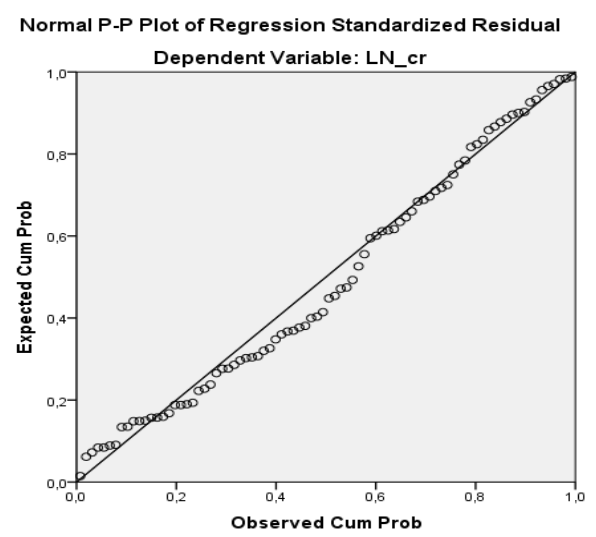

Gambar 2. Uji Normalitas P-P Plot Sumber : Hasil Pengolahan Data, 2019 
Hasil uji grafik Normalitas P-P Plot pada Gambar 2 terlihat titik-titik menyebar mendekati garis diagonal, maka dapat disimpulkan data berdistribusi normal.

Tabel 2. Uji Normalitas Kolmogorov Smirnov Setelah Transformasi

\begin{tabular}{ll|r}
\hline & & Understandardized Residual \\
\hline $\mathrm{N}$ & & 84 \\
Normal Parameters & & \\
& Mean &, 0000000 \\
Most Extreme Differences & Std.Deviation &, 48537075 \\
& Absolute &, 087 \\
& Positive &, 087 \\
Test Statistic & Negative &,- 046 \\
Asymp. Sig. (2-tailed) & &, 087 \\
\hline
\end{tabular}

Sumber : Hasil Pengolahan Data, 2019

Hasil uji normalitas Kolmogorov Smirnov Kolmogorov Smirnov dapat diambil menunjukkan nilai signifikan $0,167>0,05$. kesimpulan data berdistribusi normal. Dengan demikian hasil uji normalitas

\section{Uji Multikolonieritas}

Tabel 3. Uji Multikolonieritas

\begin{tabular}{|c|c|c|c|c|c|c|c|}
\hline \multirow[b]{2}{*}{ Mode } & \multicolumn{2}{|c|}{$\begin{array}{l}\text { Unstandardized } \\
\text { Coefficients }\end{array}$} & \multirow{2}{*}{$\begin{array}{c}\text { Standardized } \\
\text { Coefficients }\end{array}$} & \multirow{2}{*}{$\mathrm{T}$} & \multirow{2}{*}{ Sig. } & \multicolumn{2}{|c|}{$\begin{array}{l}\text { Collinearity } \\
\text { Statistics }\end{array}$} \\
\hline & $\mathrm{B}$ & Std.Error & & & & Tolerance & VIF \\
\hline 1 (constant) &,- 342 & ,844 & &,- 406 & ,686 & & \\
\hline LN_perputaran_kas &,- 056 &, 019 &,- 301 & $-2,952$ &, 004 & ,998 & 1,002 \\
\hline LN_modal_kerja & 049 &, 030 & , 164 & 1,600 &, 114 & ,989 & 1,011 \\
\hline LN perputaran piutang & 091 & 046 & 202 & 1,972 &, 052 & ,991 & 1,009 \\
\hline
\end{tabular}

Sumber : Hasil Pengolahan Data, 2019

Berdasarkan hasil pengolahan data pada Tabel 3. besarnya nilai tolerance variabel perputaran kas, modal kerja dan perputaran piutang berada diatas 0,10 sedangkan nilai VIF variabel perputaran kas, modal kerja dan perputaran piutang berada dibawah 10. Dengan demikian hasil uji multikolonieritas setelah transformasi tidak terjadi regresi antar variabel independen. 


\section{Uji Autokorelasi}

Tabel 4. Uji Autokorelasi

Model Summary ${ }^{b}$

\begin{tabular}{c|c|c|c|c|c}
\hline Model & $\mathrm{R}$ & $\mathrm{R}$ Square & $\begin{array}{c}\text { Adjuster R } \\
\text { Square }\end{array}$ & $\begin{array}{c}\text { Std. Error of } \\
\text { the Estmate }\end{array}$ & Durbin-Watson \\
\hline 1 &, $411^{\mathrm{a}}$ &, 169 &, 137 &, 49439 & 2,241 \\
\hline
\end{tabular}

Sumber : Hasil Pengolahan Data, 2019

Hasil uji Durbin-Watson menunjukkan angka 2,241, sedangkan dalam tabel DW untuk " $\mathrm{k} "=3$ (jumlah variabel bebas) dan $\mathrm{n}=96$ (jumlah data) besar nilai dl (batas bawah) = 1,6039 dan $\mathrm{du}=($ batas atas $)=1,7326 ; 4-\mathrm{dl}=$
2,3961 dan 4-du $=2,2674$. Dengan melihat kriteria pada pedoman Durbin-Watson maka nilai $\mathrm{du}<\mathrm{dw}<4-\mathrm{du}$ atau $1,7326<2,241<$ 2,2674 maka dapat disimpulkan tidak terjadi autokorelasi dalam penelitian ini.

\section{Uji Heteroskedastisitas}

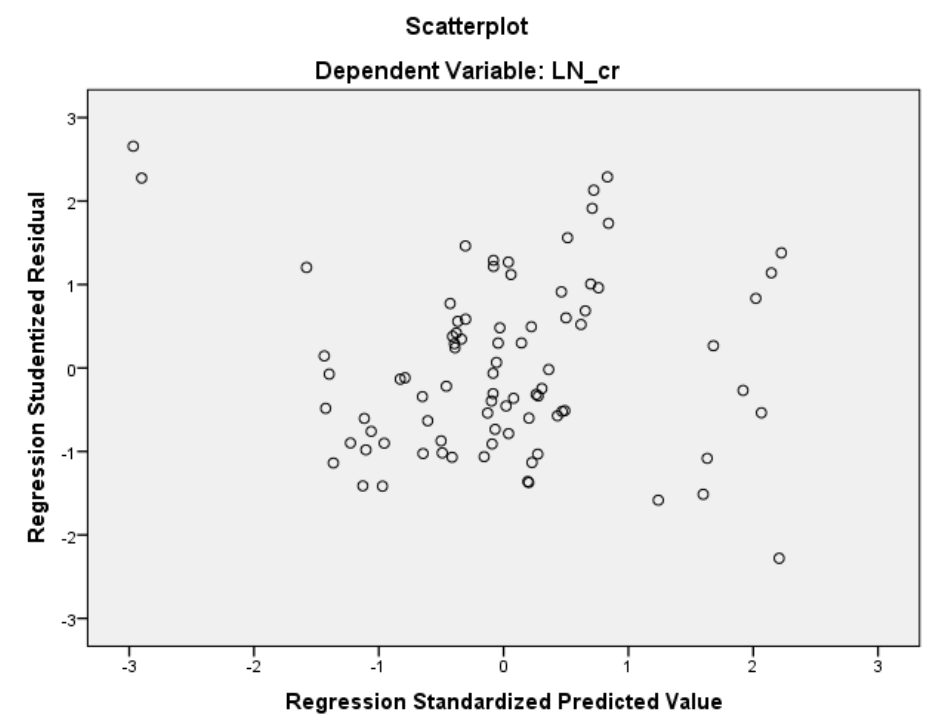

Gambar 3. Uji Heteroskedastisitas

Sumber : hasil perngolahan data, 2019

Pada gambar 3. terlihat bahwa titik-titik menyebar secara acak baik di atas maupun di bawah angka nol (0) pada sumbu Y, tidak berkumpul di satu tempat, sehingga dari grafik scetterplot dapat disimpulkan bahwa tidak terjadi heteroskedastisitas pada model regresi. 
Tabel 5.Uji Glejser Setelah Transformasi

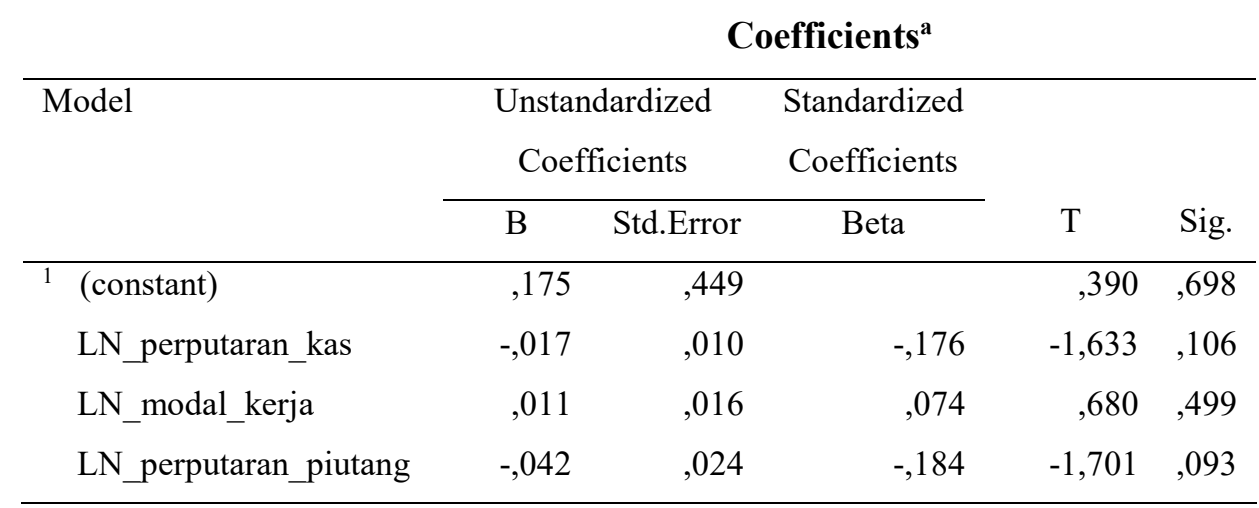

Sumber : Hasil Pengolahan Data, 2019

Hasil uji glejser pada tabel 5. menunjukkan nilai signifikan dari ketiga variabel independen (perputaran kas, modal kerja dan perputaran piutang) lebih besar dari 0,05. Dengan demikian dari hasil uji glejser dapat disimpulkan tidak terjadi masalah heteroskedastisitas.

\section{Analisis Regresi Berganda}

Tabel 6. Persamaan Regresi

\section{Coefficients $^{\mathrm{a}}$}

\begin{tabular}{lrrrrrr}
\hline & \multicolumn{2}{c}{$\begin{array}{c}\text { Unstandardized } \\
\text { Coefficients }\end{array}$} & \multicolumn{2}{c}{$\begin{array}{c}\text { Standardized } \\
\text { Coefficients }\end{array}$} & & \\
\cline { 2 - 4 } Model & \multicolumn{1}{c}{ B } & Std.Error & Beta & & \multicolumn{1}{c}{ Sig. } \\
\hline 1 (constant) &,- 342 &, 844 & &,- 406 &, 686 \\
& LN_perputaran_kas &,- 056 &, 019 &,- 301 & $-2,952$ &, 004 \\
LN_modal_kerja &, 049 &, 030 &, 164 & 1,600 &, 114 \\
\multicolumn{1}{l}{ LN_perputaran_piutang } &, 091 &, 046 &, 202 & 1,972 &, 052 \\
\hline
\end{tabular}

Sumber : Hasil Pengolahan Data, 2019

\section{LN LIKUIDITAS $=(-0,342)+(-0,056)$ LN PERPUTARAN KAS + 0,049 LNMODAL KERJA - 0,091 PERPUTARAN PIUTANG}

Tabel 6. menunjukkan untuk variabel Perputaran kas adalah sebesar -0,056. Artinya jika Perputaran Kas mengalami kenaikan 1\% maka Likuiditas (Y) akan mengalami peningkatan sebesar $-0,056$. Untuk variabel Modal Kerja adalah sebesar 0,049. Artinya jika Modal Kerja mengalami kenaikan 1\% maka
Likuiditas (Y) akan mengalami peningkatan sebesar 0,049. Untuk variabel Perputaran Piutang adalah sebesar 0,091. Artinya jika Perputaran Piutang mengalami kenaikan 1\% maka Likuiditas (Y) akan mengalami peningkatan sebesar 0,091 . 


\section{Analisis Koefisien Determinasi ( $\left.\mathbf{R}^{\mathbf{2}}\right)$}

Tabel 7.Uji Koefisien Determinasi

Model Summary

\begin{tabular}{c|l|c|c|c}
\hline Model & R & R Square & Adjuster R Square & Std. Error of the Estmate \\
\hline 1 &, $264^{\mathrm{a}}$ &, 069 &, 035 &, 26321 \\
\hline
\end{tabular}

Sumber : Hasil Pengolahan Data, 2019

Berdasarkan tabel 7, hasil uji koefisien determinasi diperolah nilai Adjusted R Square sebesar 0,35 . hal ini berarti $35 \%$ dari variasi variabel dependen Likuiditas yang dapat dijelaskan oleh variabel independen perputaran kas, modal kerja, perputaran piutang sedangkan sisanya sebesar 65\% (100\%-35\%) dijelaskan oleh variabel-variabel lain diluar dari variabel yang di teliti misalnya Pendapatan terhadap laba bersih.

\section{Uji Hipotesis Secara Simultan (Uji F)}

Tabel 8. Uji Hipotesis Secara simultan ( Uji F)

\begin{tabular}{|c|c|c|c|c|c|c|}
\hline \multirow{2}{*}{\multicolumn{2}{|c|}{ Model }} & \multicolumn{5}{|c|}{ ANOVA $^{\mathrm{a}}$} \\
\hline & & Sum of Squares & Df & Mean Square & $\mathrm{F}$ & Sig \\
\hline 1 & Regression & ,414 & 3 & , 138 & 1,990 &, $122^{\mathrm{b}}$ \\
\hline & Residueal & 5,543 & 80 & 069 & & \\
\hline & Total & 5,956 & 83 & & & \\
\hline
\end{tabular}

Sumber : Hasil Pengolahan Data, 2019

Berdasarkan tabel 8, Uji F setelah transformasi diatas, menunjukkan bahwa niali $\mathrm{F}_{\text {hitung }}$ adalah 1,990 dengan tingkat signifikasi 0,122. Sedangkan $F_{\text {tabel }}$ sebesar 2,70 dengan nilai sidnifikan sebesar 0,05 . Hal ini menunjukkan bahwa $\mathrm{F}_{\text {hitung }}<\mathrm{F}_{\text {tabel }}$ atau signifikan 1,990< 2,70 dan $0,122>0,05$ yang berarti bahwa $\mathrm{H}_{0}$

\section{Uji Hipotesis Secara Parsial (Uji T)}

Tabel 9. Uji Hipotesis secara Parsial (Uji T) diterima dan $\mathrm{H}_{\mathrm{a}}$ ditolak yang berarti bahwa pengaruh perputaran kas, modal kerja dan perputaran piutang secara simultan tidak berpengaruh terhadap likuiditas pada perusahaan consumer good yang terdaftar di Bursa Efek Indonesia tahun 2014-2017.

\section{Coefficients $^{\mathrm{a}}$}

\begin{tabular}{lrrrrrr}
\hline & \multicolumn{2}{c}{$\begin{array}{c}\text { Unstandardized } \\
\text { Coefficients }\end{array}$} & \multicolumn{2}{c}{$\begin{array}{c}\text { Standardized } \\
\text { Coefficients }\end{array}$} & & \\
\cline { 2 - 4 } Model & \multicolumn{1}{c}{ B } & Std.Error & Beta & \multicolumn{1}{c}{$\mathrm{t}$} & \multicolumn{1}{c}{ Sig. } \\
\hline 1 (constant) &,- 342 &, 844 & &,- 406 &, 686 \\
LN_perputaran_kas &,- 056 &, 019 &,- 301 & $-2,952$ &, 004 \\
LN_modal_kerja &, 049 &, 030 &, 164 & 1,600 &, 114 \\
LN_perputaran_piutang &, 091 &, 046 &, 202 & 1,972 &, 052 \\
\hline \multicolumn{2}{l}{ Sumber : hasil pengolahan data, 2019} & & & &
\end{tabular}

Sumber : hasil pengolahan data, 2019 
Pada tabel 9, Nilai $\mathrm{T}_{\text {tabel }}$ untuk probabilita 0,05 pada derajat bebas 96 adalah sebesar 1,98498. Dengan demikian hasil dari uji hipotesis secara parsial (uji t) dapat dijelaskan sebagai berikut:

Hasil perhitungan uji $t$ variabel perputaran kas secara parsial diperoleh nilai $t_{\text {hitung }}$ sebesar $-2,952$ dengan nilai signifikan sebesar 0,004 sedangkan nilai $\mathrm{T}_{\text {tabel }}$ sebesar 1,98498 dengan nilai signifikan sebesar 0,05. Maka kesimpulannya adalah nilai $-\mathrm{t}_{\text {hitung }}<-\mathrm{t}_{\text {tabel }}$ $(-2,952<1,98498)$, dengan nilai signifikan $0,004<0,05$ maka $\mathrm{H}_{0}$ ditolak dan $\mathrm{H}_{\mathrm{a}}$ diterima, artinya variable perputaran kas secara parsial berpengaruh dan signifikan terhadap likuiditas pada perusahaan consumer goods yang terdaftar di Bursa Efek Indonesia periode 2014-2017.

Hasil perhitungan uji t variabel modal kerja secara parsial diperoleh nilai $t_{\text {hitung }}$ sebesar 1,600 dengan nilai signifikan sebesar 0,114, sedangkan nilai $t_{\text {tabel }}$ sebesar 1,98498 dengan nilai signifikan 0,05. Maka dapat disimpulkan bahwa nilai $\mathrm{t}_{\text {hitung }}<\mathrm{t}_{\text {tabel }} \quad(1,600<1,98498)$, dengan nilai signifikan $0,114>0,05$, maka $\mathrm{H}_{0}$ diterima dan $\mathrm{H}_{\mathrm{a}}$ ditolak, artinya variabel modal kerja secara parsial tidak berpengaruh dan signifikan terhadap likuiditas pada perusahaan consumer goods yang terdaftar di Bursa Efek Indonesia periode 2014-2017.

Hasil perhitungan uji $\mathrm{t}$ variabel perputaran kas secara parsial diperoleh nilai $t_{\text {hitung }}$ sebesar 1,972 dengan nilai signifikan sebesar 0,052 sedangkan nilai $t_{\text {tabel }}$ sebesar 1,98498 dengan nilai signifikan 0,05 . Maka dapat disimpulkan bahwa nilai $t_{\text {hitung }}<t_{\text {tabel }}$
$(1,972<1,98498)$, dengan nilai signifikan $0,052>0,05$ maka $\mathrm{H}_{0}$ diterima dan $\mathrm{H}_{\mathrm{a}}$ ditolak, artinya variabel perputaran piutang secara parsial tidak berpengaruh dan signifikan terhadap likuiditas pada perusahaan consumer goods yang terdaftar di Bursa Efek Indonesia periode 2014-2017.

\section{Pembahasan}

\section{Pengaruh Perputaran Kas Terhadap Likuiditas}

Hasil analisis menunjukan bahwa secara Parsial Perputaran Kas berpengaruh dan singnifikan terhadap Likuiditas pada perusahaan Consomer Goods yang terdaftar di Bursa Efek Indonesia periode 2014-2017.

Hasil penelitian ini tidak sependapat dengan hasil penelitian yang dilakukan oleh Astuti,Eka (2014) dengan judul pengaruh perputaran piutang dan perputaran kas terhadap Likuiditas. Berdasarkan penelitian tersebut diperoleh bahwa perputaran kas tidak berpengaruh dan signifikan terhadap likuiditas pada perusahaan barang konsumsi yang terdaftar di Bursa Efek Indonesia periode 2011.

\section{Pengaruh Modal Kerja terhadap Likiditas}

Hasil analisis menunjukkan bahwa secara parsial modal kerja tidak berpengaruh terhadap likuiditas pada perusahaan Consomer Goods yang terdaftar di Bursa Efek Indonesia periode 2014-2017.

Hasil penelitian ini tidak sependapat dengan hasil penelitian yang dilakukan oleh Chakiki, Noer (2016) dengan judul penagruh perputaran piutang dan perputaran modal kerka 
terhadap likuiditas. Berdasarkan penelitian tersebut diperolah bahwa variable perputaran modal kerja juga memiliki hubungan yang kuat dengan arah negative sebesar 4,346 pada perusahaan consumer goods yang terdaftar di Bursa Efek Indonesia Periode 2014-2017.

\section{Pengaruh Perputaran Piutang Terhadap Likuiditas}

Hasil analisis menunjukkan bahwa secara parsial perputaran piutang tidak berpengaruh terhadap likuiditas pada perusahaan Consomer Goods yang terdaftar di Bursa Efek Indonesia periode 2014-2017.

Hasil penelitian ini tidak sependapat dengan hasil penelitian yang dilakukan oleh Runtulalo, Rauna et al (2018) yang menyatakan bahwa perputaran piutang berpengaruh secara signifikan terhadap likuiditas pada Finance Institusion yang terdaftar di Bursa Efek Indonesia periode 2013-107.

\section{Kesimpulan Dan Saran}

\section{Kesimpulan}

Kesimpulan dari penelitian adalah: 1) Secara parsial perputaran kas berpengaruh negatif terhadap likuiditas pada perusahaan consumer good yang terdaftar di Bursa Efek Indonesia periode 2014-2017; 2) Secara parsial modal kerja tidak berpengaruh terhadap likuiditas pada perusahaan Consomer Goods yang terdaftar di Bursa Efek Indonesia periode 2014-2017; 3) Secara parsial perputaran piutang tidak berpengaruh terhadap likuiditas pada perusahaan Consomer Goods yang terdaftar di Bursa Efek Indonesia periode
2014-2017; dan 4) Secara simultan perputaran kas, modal kerja dan perputaran piuatng tidak berpegaruh terhadap Likuiditas pada perusahaan Consomer Goods yang terdaftar di Bursa Efek Indonesia periode 2014-2017.

\section{Saran}

Berdasarkan hasil penelitian dan pembahasan yang telah dilakukan, selanjutnya saran-saran yang dapat disampaikan melalui hasil penelitian agar mendapatkan hasil yang lebih baik adalah sebagi berikut: 1) Bagi perusahaan dapat lebih meperhatikan dan meningkatkan kinerja keuangan di perusahaan agar dapat menarik dan meningkatkan kepercayaan investor untuk berinvestasi diperusahaan; 2) Bagi investor harus memperhatikan macam-macam faktor yang dapat mempengaruhi likuiditas untuk berinvestasi di perusahaan yang diinginkan. Dalam hal ini investor dapat melihat faktorfaktor yang terkait dalam perusahaan seperti perputaran kas, modak kerja, perputaran piutang; 3) Penelitian selanjutnya diharapkan dapat menggunakan objek penelitian yang lebih luas, tidak hanya perusahaan perbankan atau pada industrilannya, dapat menggunakan periode pengamatan yang lebih panjang. Selan itu, dapat menggunkan faktor-foktor external lainnya seperti tingkat suku bunga, inflasi.

\section{Daftar Pustaka}

\section{Jurnal:}

Astuti, Eka. 2014. Pengaruh Perputaran Piutang dan Perputaran Kas terhadap Likuiditas. Jurnal Studia Akuntansi dan Bisnis Vol.1 No. 1, pp.23376112. 
Cakiki, Noer. 2016. Pengaruh Perputaran Piutang dan Perputaran Modal Kerja terhadap Likuiditas pada Perusahaan Consumer Good. Jurnal Ilmu dan Riset Manajemen: Volume 5, No 9, pp.2461-0593

Runtulalo, Rauna et al. 2018. Pengaruh Perputaran Kas dan Piutang terhadap Likuiditas pada Perusahaan Finance Institution yang Terdaftar di Bursa Efek Indonesia periode 2013-2017. Jurnal EMBA,Vol 6. No 4. Pp.28382847.

\section{Buku:}

Fahmi, Irham. 2016. Manajemen keuangan. Bandung : Penerbit Alfabeta.

Jumingan. 2014. Analisis Laporan Keuangan. Jakarta :Penerbit PT. Bumi aksara
Kasmir.2012. Analisis Laporan Keuangan. Edisi Keempat. Yogyakarta :Penerbit PT. Reja Grafindo Persada.

$\longrightarrow$ 2010,Manajemen keuangan Edisi pertama Jakarta Penerbit, Kencana.

M.Hanafi. 2012. Analisis laporan keuangan. Edisi keempat Yogyakarta.

Rudianto. 2009. Pengantar Akuntansi. Jakarta : Penerbit Erlangga

Sudana, 2011. Manajemen Keuangan. Penerbit PT Gelora Aksara Pratama

Sunyoto. 2013. Manajemen Sumber Daya Alam. Cetakan kedua : Yogyakarta 